\title{
Enhancement of the folate content in Egyptian pita bread
}

\author{
Mohammed Hefni ${ }^{1,2}$ and Cornelia M. Witthöft ${ }^{1 *}$ \\ 'Department of Food Science, Swedish University of Agricultural Sciences, Uppsala, Sweden; ${ }^{2}$ Department of Food \\ Industries, Mansoura University, Mansoura, Egypt
}

\section{Abstract}

Introduction: Egypt has a high incidence of neural tube defects related to folate deficiency. One major food source for folate is pita (baladi) bread, which is consumed daily. Bioprocessing (e.g. germination) has been reported to increase the folate content in cereals. The aim was to produce pita bread with increased folate content using germinated wheat flour (GWF).

Methods: Prior to milling the effects of germination and drying conditions on folate content in wheat grains were studied. Pita bread was baked from wheat flour substituted with different levels of GWF. The folate content in dough and bread and rheological properties of dough were determined.

Results: Germination of wheat grains resulted in, depending on temperature, 3- to 4-fold higher folate content with a maximum of $61 \mu \mathrm{g} / 100 \mathrm{~g}$ DM (dry matter). The folate content in both flour and bread increased 1.5 to 4-fold depending on the level of flour replacement with GWF. Pita bread baked with $50 \%$ sieved GWF was acceptable with respect to colour and layer separation, and had a folate content of $50 \mu \mathrm{g} / 100$ g DM compared with $30 \mu \mathrm{g} / 100 \mathrm{~g}$ DM in conventional pita bread $(0 \% \mathrm{GWF})$.

Conclusion: Using 50\% GWF, pita bread with increased folate content, acceptable for the Egyptian consumer, was produced. Consumption of this bread would increase the average daily folate intake by $75 \mu \mathrm{g}$.

Keywords: wheat grains; bioprocessing; germination; baladi bread; folate

$\mathrm{E}$ gypt has an estimated incidence of neural tube defects of $4.5 / 1,000$ pregnancies $(1,2)$ indicating that folate deficiencies exist in several population groups (3). One of the important folate sources in Egypt is wheat flour with a per capita consumption as high as $363 \mathrm{~g} /$ day, providing about $66 \%$ energy (4). Wheat flour is almost completely consumed in the form of pita bread, which in Egypt is referred to as baladi bread. It is circular, flat bread with almost no crumbs forming a pocket from two layers (Fig. 1) and is produced from high extraction rate wheat flour. There is no agreement on characteristics to judge the quality of pita bread (5) but layer separation, crust, shape, and colour are the parameters for subjective evaluation. No representative folate intake data are available for Egypt, but it was estimated that cereal foods could contribute with ca $60 \%$ to the daily folate intake (6).

Recently in 2010, Egypt introduced mandatory folic acid and iron fortification of the flour used for the production of subsidised pita bread (7; personal communication with Prof Azza Gohar, National Nutrition
Institute, Cairo, Egypt) to reduce incidence of both neural tube defect pregnancies and anaemia. However, there is still a debate regarding the ambiguous role of synthetic folic acid in promotion of, for example, colorectal cancer (8) and other potential adverse or positive health effects (9-12). Therefore, careful monitoring and adjustment of the fortification level is necessary after beginning the fortification programme and complementive approaches to enhance folate intake in the Egyptian population are demanded.

Different methods of bioprocessing (e.g. fermentation and germination) have been shown to increase the content of folate and other micronutrients in cerealgrain and other foods (13-17), and several of these methods are commonly used during household and industrial production of traditional and contemporary Egyptian foods.

An aim of the current study was to increase the folate content in pita bread using a traditional Egyptian household procedure for the preparation and as candidate functional ingredient germinated wheat flour. 

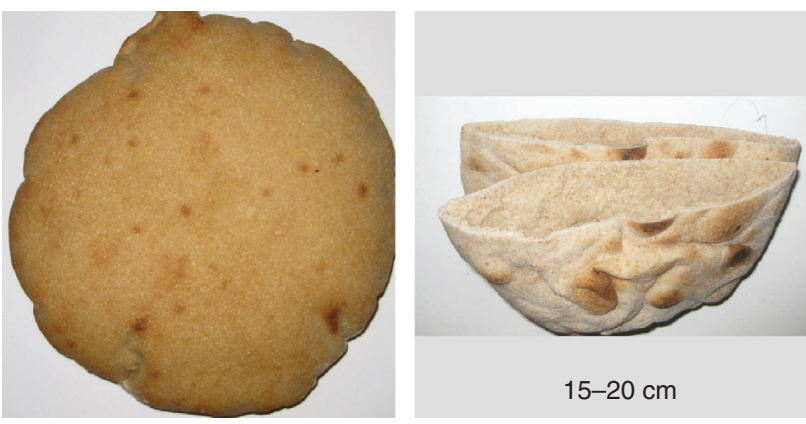

Fig. 1. Traditional Egyptian pita bread (left - from above, right - cut open).

\section{Material and methods}

\section{Food samples}

Wheat grains (triticum aestivum) and wheat flour (extraction rate $82 \%$ ) were supplied from Lantmännen, Järna, Sweden. Grains were harvested in the year 2008 and derived from an unknown mix of varieties commonly grown in Sweden. Dried yeast (Kronjäst, Jästbolaget, Sollentuna, Sweden) was purchased in a food store in Uppsala.

\section{Experimental}

Germination and drying experiments and subsequent milling for the preparation of wheat flour for pita bread baking were carried out as depicted in Fig. 2. Germination was carried out in a leavening cupboard (Elektro Helios, Stockholm, Sweden) during $48 \mathrm{hr}$ at 20, 25, 30, and $35^{\circ} \mathrm{C}$. The following drying conditions for wheat germ (germinated at $30^{\circ} \mathrm{C}$ ) were tested using a drying oven (Heraeus, D-63450, Hannover, Germany): $35^{\circ} \mathrm{C}$ for

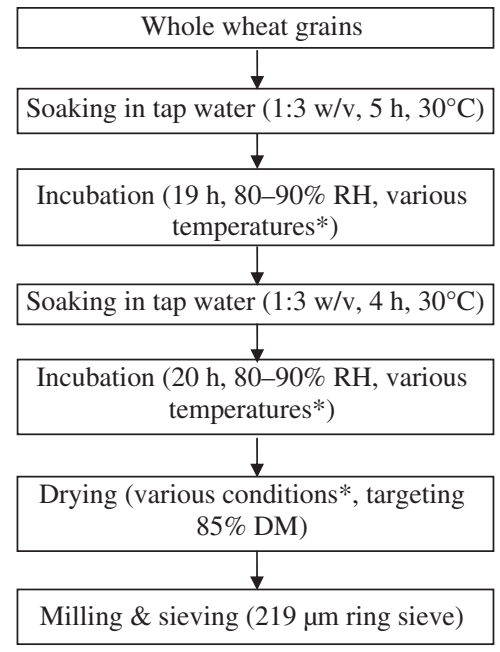

$6 \mathrm{hr} ; 50^{\circ} \mathrm{C}$ for $4 \mathrm{hr} ; 70^{\circ} \mathrm{C}$ for $2 \mathrm{hr}$; and $90^{\circ} \mathrm{C}$ for $1 \mathrm{hr}$, aiming for a final dry matter (DM) of $85 \%$.

Pita bread was baked using a sponge dough method (Fig. 2; 300 g flour, $1.5 \mathrm{~g}$ dried yeast, $3 \mathrm{~g} \mathrm{NaCl}, 3 \mathrm{~g}$ sugar, $174 \mathrm{ml}$ water), using flour (extraction rate 82\%) substituted with $0,25,50$, or $100 \%$ sieved $(219 \mu \mathrm{m})$ germinated $\left(30^{\circ} \mathrm{C}\right.$ for $48 \mathrm{hr}$, Fig. 2) wheat flour.

Folate content in dough and bread samples was quantified using HPLC (6). DM in cereal, dough, and bread samples was determined according to AOAC (18). Rheological properties of the dough were determined by farinograph (Brabender OHG, Duisburg, Germany) according to AACC (19).

Data are expressed as mean and standard error of mean (SEM) from duplicate trials and duplicate analysis. The sum of quantified folate forms (tetrahydrofolate, 5-methyl-tetrahydrofolate, and 10-formyl-folic acid) was after correction for molecular weights expressed as folic acid in $\mu \mathrm{g} / 100 \mathrm{~g}$ DM (20). Treatments and their effect on folate content were compared using the general linear model. Effects of the different conditions within each treatment were analysed using Tukey's pairwise comparison (SAS, version 9.1, SAS Institute Inc., Cary, NC, USA); differences were considered significant at $p>0.05$.

\section{Results and discussion}

Germination of wheat grains resulted, in accordance to findings by others $(16,17)$, in a 3 - to 4 -fold higher folate content as compared to the initial $14 \mu \mathrm{g} / 100 \mathrm{~g}$ (Fig. 3). Maximum folate content was found after germination at 25 and $30^{\circ} \mathrm{C}$ (Fig. 3). The folate content of unsieved and sieved germinated wheat flour (GWF) (after germination at $30^{\circ} \mathrm{C}$ ) was $72+3 \mu \mathrm{g} / 100 \mathrm{~g}$ and $56+3 \mu \mathrm{g} / 100 \mathrm{~g}$ DM. Drying of germinated wheat grains did not significantly

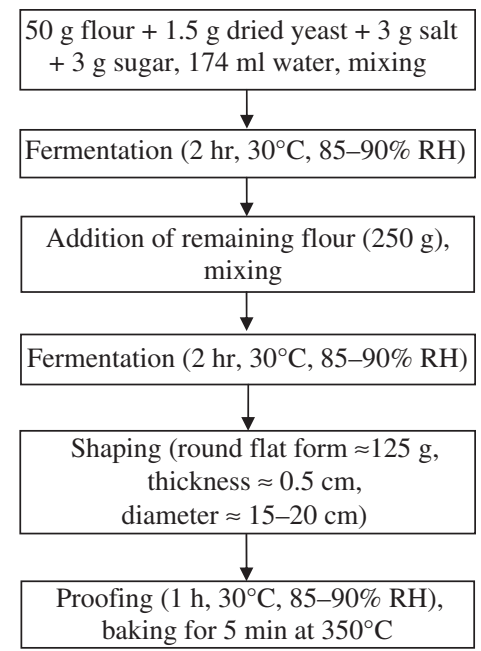

Fig. 2. Preparation of germinated wheat flour (left) and pita bread baking (right). *Germination was carried out at 20, 25, 30, and $35^{\circ} \mathrm{C}$. Drying conditions were $35^{\circ} \mathrm{C}$ for $6 \mathrm{hr}, 50^{\circ} \mathrm{C}$ for $4 \mathrm{hr}, 70^{\circ} \mathrm{C}$ for $2 \mathrm{hr}$, and $90^{\circ} \mathrm{C}$ for $1 \mathrm{hr}$. $\mathrm{RH}=$ relative humidity, $\mathrm{DM}=$ dry matter. 


\begin{tabular}{|c|c|c|c|c|}
\hline Native & \multicolumn{4}{|c|}{ Germinated wheat grains } \\
\hline wheat grains & $20^{\circ} \mathrm{C}$ & $25^{\circ} \mathrm{C}$ & $30^{\circ} \mathrm{C}$ & $35^{\circ} \mathrm{C}$ \\
\hline $1.1 \mathrm{~s} \times 11$ & inger & $\frac{-2}{4}+2$ & & 23 \\
\hline $\begin{array}{c}14 \pm 0.6^{c} \\
\mu g / 100 \text { g DW }\end{array}$ & $\begin{array}{c}43 \pm 2.4^{b} \\
\mu \mathrm{g} / 100 \mathrm{~g} \mathrm{DW}\end{array}$ & $\begin{array}{c}56 \pm 0.6^{\mathrm{a}} \\
\mu \mathrm{g} / 100 \mathrm{~g} \mathrm{DW}\end{array}$ & $\begin{array}{c}61 \pm 2.3^{a} \\
\mu g / 100 \mathrm{~g} \mathrm{DW}\end{array}$ & $\begin{array}{c}42 \pm 3.7^{\mathrm{b}} \\
\mu \mathrm{g} / 100 \mathrm{~g} \mathrm{DW}\end{array}$ \\
\hline
\end{tabular}

Fig. 3. Folate content $(\mu \mathrm{g} / 100 \mathrm{~g} \mathrm{DM} \pm \mathrm{SEM})$ in native and germinated wheat grains at different temperatures. Folate values (means from duplicate trials and duplicate analyses) are the sum of quantified folate forms (tetrahydrofolate, 5-methyltetrahydrofolate, and 10-formyl-folic acid) expressed as folic acid after correction for molecular weights. Different superscripts represent significant differences $(p<0.05)$.

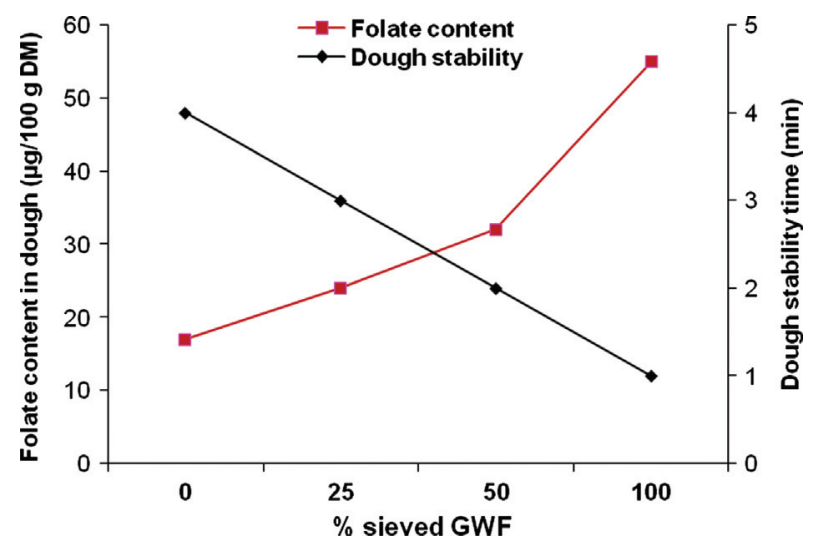

Fig. 4. Folate content $(\mu \mathrm{g} / 100 \mathrm{~g}$ DM) and dough stability time (min) in dough samples prepared after substitution with sieved germinated wheat flour (GWF). Folate values (means from duplicate trials and duplicate analyses) are the sum of quantified folate forms (tetrahydrofolate, 5-methyl-tetrahydrofolate, and 10-formyl-folic acid) expressed as folic acid after correction for molecular weights. Dough stability data are derived from duplicate trials.

( $p=0.61)$ affect the folate content as compared to fresh germinated grains, resulting in a folate content of 56-72 $\mu \mathrm{g} / 100 \mathrm{~g}$ DM.
The addition of increasing amounts of sieved germinated wheat flour resulted in enhanced folate content in dough, but rheological properties were affected adversely (Fig. 4). Baking of pita bread after addition of various amounts of sieved germinated wheat flour resulted in a net increase of folate content in both flour and bread (Fig. 5). Pita bread baked with 50\% sieved GWF was acceptable with respect to taste, colour, and layer separation (data not shown; 20), and had a folate content of $50 \mu \mathrm{g} / 100 \mathrm{~g}$ DM compared with $30 \mu \mathrm{g} / 100 \mathrm{~g}$ DM in conventional bread ( $0 \%$ GWF). Fermentation of dough increased the folate content (Fig. 6); similar observations were reported for other types of bread $(13,14)$. Subsequent baking of the pita bread did not affect the folate content (Fig. 6).

\section{Conclusions}

Egyptian pita bread with enhanced folate content of 50 $\mu \mathrm{g} / 100 \mathrm{~g}$ (compared to $30 \mu \mathrm{g} / 100 \mathrm{~g}$ using native wheat flour) could be produced by adding 50\% sieved GWF. Consumption of this bread would increase the average daily folate intake by approximately $75 \mu \mathrm{g}$.

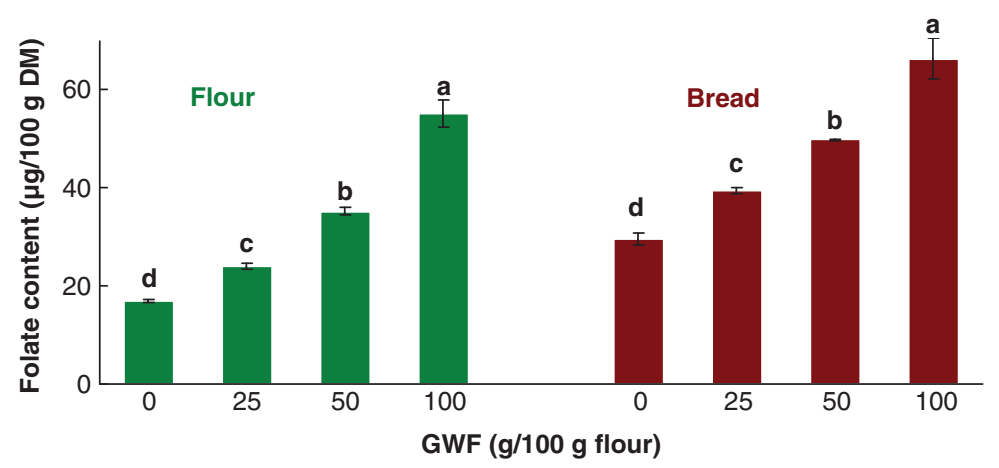

Fig. 5. Folate content ( $\mu \mathrm{g} / 100 \mathrm{~g} \mathrm{DM}, \pm \mathrm{SEM})$ in flour (left, green bars) and bread (right, maroon bars) after substitution with sieved GWF. Folate values (means from duplicate trials and duplicate analyses) are the sum of quantified folate forms (tetrahydrofolate, 5-methyl-tetrahydrofolate, and 10-formyl-folic acid) expressed as folic acid after correction for molecular weights. Bars with different letters within the same group are significantly different $(p<0.05)$. 


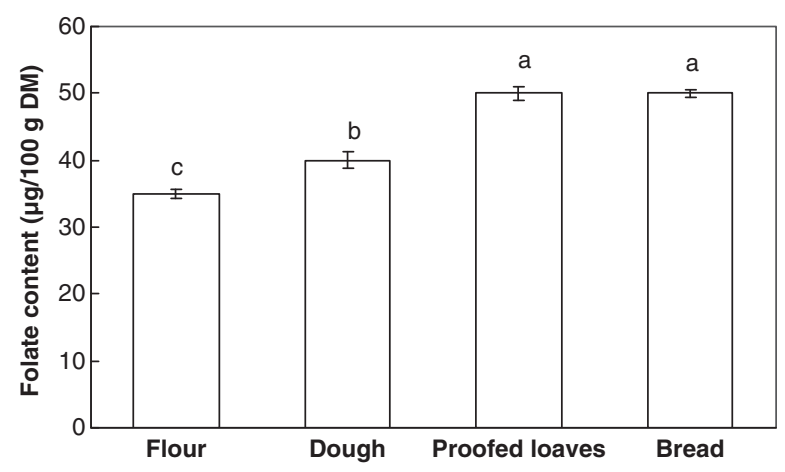

Fig. 6. Net increase of folate content $(\mu \mathrm{g} / 100 \mathrm{~g} \mathrm{DM}, \pm \mathrm{SEM})$ in pita bread with $50 \%$ sieved GWF during baking. Folate values (means from duplicate trials and duplicate analyses) are the sum of quantified folate forms (tetrahydrofolate, 5-methyl-tetrahydrofolate, and 10-formyl-folic acid) expressed as folic acid after correction for molecular weights. Bars with different letters are significantly different $(p<$ $0.05)$.

\section{Acknowledgements}

The authors of this extended abstract acknowledge the reproduction of essential information from 'Increasing the folate content in Egyptian baladi bread using germinated wheat flour' by Hefni and Witthöft. Thanks are due to LWT - Food Science and Technology for giving us permission to reproduce parts of this article.

\section{Conflict of interest and funding}

A PhD grant $(\mathrm{MH})$ from the Egyptian Ministry of Higher Education is gratefully acknowledged. We would like to thank Lantmännen R\&D, Järna, Sweden, for supplying the wheat grains and flour and Lantmännen Mills AB, Uppsala, Sweden, for the milling. Folate standards were a kind gift from Merck Eprova AGF, Schaffhausen, Switzerland.

\section{References}

1. Flour Fortification Initiative (FF). FFI country information: Egypt. Overview of progress toward fortification; http:// www.sph.emory.edu/wheatflour/Egypt.php; 2009 [cited 24 August 2010].

2. Temtamy SA, Abdel Maguid N, Mazen I, Ismail SR, Kassem NS, Bassiouni R. A genetic epidemiological study of malformations at birth in Egypt. EMHJ 1998; 4: 252-9.

3. Hussein L, Hermann-Kunz E, Dortschy E, Kohlmeier L, Kuhn G. Food consumption patterns and nutrient intakes among selected Egyptian population groups deferring in their socioeducation status. Egypt J Nutr 1995; 10: 75-113.

4. Food and Agricultural Organization (FAO). Food balance sheet. Egypt - 2005; http://faostat.fao.org/site/368/default. aspx\#ancor; 2005 [cited 4 November 2007].

5. Morad MM, Doherty CA, Rooney LW. Effect of sorghum variety on baking properties of US conventional bread, Egyptian pita 'balady' bread and cookies. J Food Sci 1984; 49: $1070-4$.
6. Hefni M, Öhrvik V, Tabekha M, Witthöft C. Folate content in foods commonly consumed in Egypt. Food Chem 2010; 121: $540-5$.

7. Global Alliance for Improved Nutrition (GAIN). WFP, MOSS and GAIN celebrate start of flour fortification in Egypt to reduce widespread anemia by $28 \%$; http://www.gainhealth.org/ press-releases/wfp-moss-and-gain-celebrate-start-flour-fortification-egypt-reduce-widespread-anemia-; 2009 [cited 27 November 2009].

8. Mason JB, Dickstein A, Jacques PF, Haggarty P, Selhub J, Dallal G, et al. A temporal association between folic acid fortification and an increase in colorectal cancer rates may be illuminating important biological principles: a hypothesis. Cancer Epidemiol Biomarkers Prev 2007; 16: 1325-9.

9. Boushey CJ, Beresford SA, Omenn GS, Motulsky AG. A quantitative assessment of plasma homocysteine as a risk factor for vascular disease. JAMA 1995; 274: 1049-57.

10. Seshadri S, Beiser A, Selhub J, Jacques PF, Rosenberg IH, D'Agostino RB, et al. Plasma homocysteine as a risk factor for dementia and Alzheimer's disease. N Engl J Med 2002; 346: 476-83.

11. Wald DS, Law M, Morris JK. Homocysteine and cardiovascular disease: evidence on causality from a meta-analysis. BMJ 2002; 325: 1202-6.

12. Smith AD, Kim Y-I, Refsum H. Is folic acid good for everyone? Am J Clin Nutr 2008; 87: 517-33.

13. Osseyi ES, Wehling RL, Albrecht JA. HPLC determination of stability and distribution of added folic acid and some endogenous folates during breadmaking. Cereal Chem 2001; 78: 375-8.

14. Kariluoto S, Vahteristo L, Salovaara H, Katina K, Liukkonen $\mathrm{KH}$, Piironen V. Effect of baking method and fermentation on folate content of rye and wheat breads. Cereal Chem 2004; 81: $134-9$.

15. Jägerstad M, Piironen V, Walker C, Ros G, Carnovale E, Holasova $\mathrm{M}$, et al. Increasing natural food folates through bioprocessing and biotechnology. Trends Food Sci Tech 2005; 16: 298-306.

16. Kariluoto S, Liukkonen K, Myllymäki O, Vahteristo L, Kaukovirta-Norja A, Piironen V. Effect of germination and thermal treatments on folates in rye. J Agric Food Chem 2006; 54: $9522-8$

17. Koehler P, Hartmann G, Wieser H, Rychlik M. Changes of folates, dietary fiber, and proteins in wheat as affected by germination. J Agric Food Chem 2007; 55: 4678-83.

18. AOAC. Official methods of analysis. 17th ed. Arlington, VA: Association of Official Analytical Chemists; 2000.

19. AACC. Approved methods of American association of cereal chemists. 10th ed. St Paul, MN: American Association of Cereal Chemists; 2000.

20. Hefni M, Witthöft CM. Increasing the folate content in Egyptian baladi bread using germinated wheat flour. LWTFood Sci Technol 2011; 44: 706-12.

\footnotetext{
*Cornelia M. Witthöft

Department of Food Science

Uppsala BioCenter

Swedish University of Agricultural Sciences

$\mathrm{PO}$ Box 705।

Se-75007 Uppsala Sweden

Tel: $+46(18) 671319$

Fax: $+46(18) 672995$

Email: Cornelia.Witthoft@slu.se
} 